International Journal of Language Education

Volume 5, Number 3, 2021, pp. 193-206

ISSN: $2548-8457$ (Print) 2548-8465 (Online)

Doi: https://doi.org/10.26858/ijole.v5i3.18978

\title{
Students' Metacognitive Awareness and Its Impact on Writing Skill
}

\author{
Dina Ramadhanti \\ STKIP PGRI Sumatera Barat, Indonesia \\ Email:dina_ramadhanti89@yahoo.com \\ Diyan Permata Yanda \\ Institut Agama Islam Negeri (IAIN) Bukittinggi, Indonesia \\ Email: diyan_yanda@yahoo.com
}

Received: 26 January 2021

Reviewed: 1 August 2021-30 September 2021

Accepted: 1 October 2021

\begin{abstract}
One of the factors that can affect the ability to write explanatory text is metacognitive awareness. By using the descriptive method, the students' level of metacognitive awareness was explained, and by using the correlational method the effect of metacognitive awareness towards explanatory text writing ability was explained. The results showed that as many as 25 students had a high level of awareness while 38 others had a moderate level of awareness. The relationship between metacognitive awareness variables and the ability to write explanatory text is significant and very strong seen from the range of correlation values, namely 0.812 . Metacognitive awareness affects the ability to write explanatory text by $66 \%$ and the remaining $44 \%$ is influenced by other factors. This shows that metacognitive awareness has an important role in writing. Students must always increase their metacognitive awareness. Efforts that can be made to raise students' metacognitive awareness are that lecturers carry out writing learning with a cognitive process approach to increase metacognitive knowledge and apply metacognitive strategies so that students have metacognitive skills to complete writing assignments.
\end{abstract}

Keywords: metacognitive awareness; writing

\section{Introduction}

Writing is seen as a powerful tool to stimulate thinking and learning (Greenberg, 1988) and as a medium for thinking and a vehicle for developing thoughts (Marzano et al., 1987). As a medium to stimulate and develop thinking, the process of writing involves cognitive activities, ranging from planning, translating, and reviewing (Flower \& Hayes, 1981). The writing process requires more cognitive resources. Cognitive resources are needed starting from planning of ideas, organizing and planning actions, writing actions, revising, and monitoring based on feedback on the results of the writing. In the writing process, there will be stages of text construction, handwriting, spelling, memory, and executive functions (Owens, 2012). These processes are regulated and controlled by metacognition.

Metacognition in cognitive psychological theory is seen as a form of awareness about one's cognition, how its cognition works, and how to regulate it (Flavell, 1979). The ability of 
metacognition is considered important in order to achieve efficient use of cognition in solving mathematical and language problems. Metacognition plays an important role and determines success in writing because writing products are called applied metacognition (Hacker, Keener, \& Kircher, 2009). The written product is the result of a process of control, direction, and monitoring of metacognition. Learners who are aware of their metacognition and often use metacognitive strategies in the learning process will become successful learners (Iwai, 2011; Goctu, 2017). Conversely, learners who are not aware of their own metacognition will experience problems in writing. The problem is related to the failure to apply the five competencies in writing, namely the generalization of content, the creation of organizational structures in writing, the formulation of goals and writing plans, speed and efficiency in carrying out mechanical aspects of writing, the revision of texts and the formulation of goals (Harris, Graham, Brindle, \& Sandmel, 2009).

In addition, students often experience failure in writing because they do not yet have an awareness of metacognitive knowledge. Metacognitive knowledge, namely declarative, procedural, and conditional knowledge. They do not have declarative knowledge to develop ideas, do not have conditional knowledge so they are unable to apply the right strategy, and do not have procedural knowledge so that they are not able to show the right steps in writing (Surat, Rahman, Mahamod, \& Kummin, 2014). These findings prove that metacognitive knowledge is an important aspect that can help students achieve success in writing. Success in writing is greatly influenced by the metacognitive knowledge base, such as personal, task, and strategy (Kasper, 1997).

Considering the importance of metacognition and various problems that arise in writing, it is necessary to investigate the metacognitive awareness of students in writing, both in terms of knowledge of cognition and cognitive regulation. By knowing the level of metacognitive awareness of students, then efforts can be formulated that can be made to increase the metacognitive awareness of students in writing. Previously, there has been an investigation about the metacognition weaknesses in the final year students who write final projects. While working on the academic writing task, last year students are known to have three metacognitive weaknesses, which are always dependent on others when experiencing difficulties in writing, they are not aware of the benefits of the strategies used, and are unable to assess their own understanding of the information received in writing (Ramadhanti, Ghazali, Hasanah, \& Harsiati, 2019). These weaknesses have an impact on the quality of last year's student academic writing. The final project that their results tend to be not as they should be and result in failure in the exam. Therefore, it is necessary to investigate early on the metacognitive awareness of students in writing so that they have no difficulty completing the final project as a condition of completing education in college. This investigation was conducted on third year students who were taking writing courses, both teaching writing, scientific writing, and creative writing.

One type of writing written by students is explanatory text. Explanation text is writing that intends to present the author's views on how or why something happened, why something can be the same or different, and how to solve a problem (Anderson \& Anderson, 1997a). The explanatory text was chosen with the assumption that this text demands the ability to think critically students about how and why something happens by presenting a number of facts that contain a causal relationship. To explain how and why things happen and how to solve problems in a phenomenon, students need cognition and metacognition. In addition, an investigation of metacognition in writing needs to be carried out so that both teachers and students are aware of the strengths and weaknesses carried out in the learning process so that problems in the writing process can be overcome early on. 
Thus, this article aims to answer three research questions, namely: 1) How is the level of metacognitive awareness of students on writing explanatory texts? 2) How is the effect of students' metacognition awareness on writing explanatory text skills?

\section{Research method}

Design

This research is a quantitative research using the correlational method to describe how much influence metacognitive awareness has on the ability to write explanatory texts. To describe metacognitive awareness is used Metacognitive Awareness Writing Questionaire (MAWQ) compiled by Farahian (2017) based on two main components of metacognition, namely knowledge of cognition and regulation of cognition (Maftoon, Birjandi, \& Farahian, 2014; Farahian, 2015, 2017). To describe the ability to write explanatory texts, a writing evaluation tool developed by is used Ramadhanti, Yanda, Ghazali, Hasanah, \& Harsiati, (2019). Furthermore, the correlational method was used to investigate the correlation between metacognitive awareness and explanatory text writing skills.

\section{Participants}

The Sample in this study were third-year students studying in the Indonesian Language and Literature Education Study Program, STKIP PGRI Sumatera Barat, Indonesia. A total of 63 third year male and female students were randomly selected for investigation purposes.

\section{Data collection}

The 63 participants were asked to fill out the metacognition questionnaire, namely the Metacognitive Awareness Writing Questionaire (MAWQ). The questionnaire was arranged and modified according to the metacognition component for writing explanatory texts. The questionnaire totaled 40 items. The number of statements for the knowledge of cognition is 21 items and the number of statements for the regulation of cognition is 19 items. Each statement is equipped with five answer choices, namely, strongly agree, agree, doubt, disagree, and strongly disagree. The questionnaire was completed with instructions for filling in to make it easier for participants to provide answers. Participants were asked to provide answers according to their experience in doing writing assignments, especially writing explanatory texts. Furthermore, students take a test writing explanatory text according to the instructions given.

Data analysis

By using the descriptive method, the data were analyzed to determine the level of metacognitive awareness of students in writing. By using descriptive statistics and correlational design (Fitri \& Ramadhanti, 2019), the data were analyzed to determine how much influence metacognitive awareness had on the ability to write an explanatory text based on the correlation value and the contribution value of variable X to variable Y. Data analysis used SPSS version 23. The formula used is Pearson Bivariate Correlation Analysis.

\section{Results}

The level of metacognitive awareness of students in writing explanatory text

A survey of 63 third year students using the Metacognitive Awareness Writing Questionaire (MAWQ) showed that students had a high and intermediate level of metacognitive awareness in writing. As many as 25 students have high metacognitive awareness, while 38 others 
have an intermediate metacognitive awareness level. Students who have a high level of metacognitive awareness are in the range of $75.00 \%-86.50 \%$. Students who have an intermediate level of metacognitive awareness are in the range of $59.50 \%-74.50 \%$. Not found students who have a low level of metacognitive awareness. This survey was conducted at two main levels of the metacognition component, namely knowledge of cognition and regulation of cognition.

First, knowledge of cognition. The items available for the knowledge of cognition consist of three parts, namely declarative knowledge, procedural knowledge, and conditional knowledge. Awareness of declarative knowledge is distinguished from personal knowledge (Table 1) and task knowledge (Table 2).

Students have declarative knowledge (person) or high self-knowledge (Table 1). Matters relating to self-concept and self-efficacy in writing explanatory texts are classified as high. Students said writing as a means of reflection for their knowledge and experience and felt that writing required more critical thinking and were more difficult than the other three language skills, namely listening, speaking and reading. Declarative knowledge concerning facts and public opinion is also quite high. Students have confidence that writing skills are not only dependent on talent but are obtained through intensive training, mastery of the topic, always paying attention to the appropriate vocabulary and grammar in write, and do not edit writing in the head. Students also realize that writers are adept at paying attention to the writing process, starting from planning ideas, developing ideas, and revising writing and always trying not to make mistakes in each stage of writing. However, students must always practice writing because they tend to make mistakes in terms of the structure of the text and the language of the text.

Table 1. Awareness of Declarative Knowledge (Person)

\begin{tabular}{llc}
\hline & Item & $\%$ \\
\hline 1 & $\begin{array}{l}\text { Writing becomes a means for me to reflect on all forms of knowledge and } \\
\text { experience that I have. }\end{array}$ & 77,80 \\
\hline 2 & $\begin{array}{l}\text { I find writing more difficult than listening, speaking and reading because } \\
\text { writing requires critical thinking about the topic to be written. }\end{array}$ & 80,63 \\
\hline 3 & $\begin{array}{l}\text { I believe that writing skills arise not only because of talent, but also } \\
\text { intensive practice. }\end{array}$ & 89,84 \\
\hline 4 & $\begin{array}{l}\text { I write according to the topic that I understand because it affects the } \\
\text { effectiveness of my writing. }\end{array}$ & 81,59 \\
\hline 5 & $\begin{array}{l}\text { I feel that a skilled writer needs to be aware of writing strategies, from the } \\
\text { planning of ideas, developing ideas, and revising writing. }\end{array}$ & 91,43 \\
\hline 6 & $\begin{array}{l}\text { At each stage of writing, a skilled writer tries as much as possible not to } \\
\text { make mistakes in writing. }\end{array}$ & 86,03 \\
\hline 7 & $\begin{array}{l}\text { I rarely make mistakes in writing text, both the structure of the text and the } \\
\text { linguistic rules of the text. }\end{array}$ & 53,65 \\
\hline 8 & $\begin{array}{l}\text { I feel writing while thinking about the right choice of vocabulary and } \\
\text { grammar is very important in writing. }\end{array}$ & 85,71 \\
\hline 9 & $\begin{array}{l}\text { I feel editing the writing in my head is not very effective in generating } \\
\text { ideas. Therefore, I always write down whatever I think about the topic. }\end{array}$ & 77,46 \\
\hline
\end{tabular}

Students have an intermediate level of declarative knowledge about assignments (Table 2). They understand well the organization of the text, that each text is built by the structure and language rules of the text. However, not all understand well every text genre and the development of sentences and paragraphs. In fact, they must continue to practice writing in order to present a 
cohesive and coherent paragraph until they are able to judge which writing is coherent and which is not.

Table 2. Awareness of Declarative Knowledge (Tasks)

\begin{tabular}{llc}
\hline & Item & $\%$ \\
\hline 10 & $\begin{array}{l}\text { I know various genres of texts, ranging from poetry, narrative, drama, } \\
\text { explanatory, responses/comments, information reports, expositions, }\end{array}$ & 72,70 \\
& discussion, recons/retelling stories, factual descriptive, and procedures. & \\
\hline 11 & $\begin{array}{l}\text { I realize that every text is built by the structure and language rules of the } \\
\text { text. }\end{array}$ & 89,21 \\
\hline 12 & $\begin{array}{l}\text { I am even very adept at presenting sentences and paragraphs by paying } \\
\text { attention to the elements of cohesion and coherence, starting from choosing } \\
\text { the appropriate vocabulary, structuring sentences according to syntactic }\end{array}$ & \\
& rules, and structuring sentences into coherent paragraphs and discourse. & \\
\hline 13 & I can realize writing that has a coherent relationship and one that does not. & 64,76 \\
\hline 14 & I always write with attention to the topic sentence, then develop the topic & 74,29 \\
& sentence with a few explanatory sentences. & \\
\hline
\end{tabular}

Students have weaknesses in terms of task knowledge. This affects the weakening of students' procedural knowledge in writing explanatory texts. Their knowledge in terms of planning, developing ideas, revising, and evaluating writing is at the intermediate level. Similarly, in terms of the use of the strategies used and the proper way of writing are at the intermediate level. Students must better understand the tasks and strategies that will be used in writing.

Table 3. Awareness of Procedural Knowledge

\begin{tabular}{llc}
\hline & Item & $\%$ \\
\hline 15 & $\begin{array}{l}\text { I realized the things I needed to do to plan, develop ideas, revise and } \\
\text { evaluate writing. }\end{array}$ & 68,25 \\
\hline 16 & $\begin{array}{l}\text { I have certain habits from my childhood that affect the strategies I use for } \\
\text { writing. }\end{array}$ & 64,13 \\
\hline 17 & $\begin{array}{l}\text { I know how to write texts, especially explanatory texts by paying attention } \\
\text { to the structure and language rules of texts. }\end{array}$ & 69,52 \\
\hline
\end{tabular}

Conditional knowledge and procedural knowledge of students in writing explanatory texts are at the intermediate level. Students are aware of the main problems they encounter during writing. However, they still need to understand and need to practice using effective strategies for writing, when to use the right strategy, and when to replace the incorrect strategy with a strategy which is more effective.

Table 4. Awareness of Conditional Knowledge

\begin{tabular}{llc}
\hline & Item & $\%$ \\
\hline 18 & $\begin{array}{l}\text { I know when to use the right strategy in writing, starting from planning, } \\
\text { developing ideas, and evaluating writing. }\end{array}$ & 63,17 \\
\hline 19 & I even realized the most effective writing strategy for me to use in writing. & 61,59 \\
\hline 20 & I know the way I have to do it when the strategy I use is not effective. & 65,71 \\
\hline 21 & $\begin{array}{l}\text { I realize the main problems encountered in writing and which parts need } \\
\text { more attention than others. }\end{array}$ & 75,56 \\
\hline
\end{tabular}


Second, Regulation of Cognition. The items available to determine the metacognitive awareness of students in terms of the regulation of cognition or metacognitive strategies include three components, namely planning (Table 5), monitoring (Table 6), and evaluation (Table 7).

The planning component in the regulation of cognition is related to the planning and drafting of the writing and consideration of the reader. The metacognitive awareness of students in relation to the planning stage is at the intermediate level. Most students felt they had problems in the initial planning, especially in the language resources to be used and often had difficulty starting writing. However, they try to get used to reading before writing, making a written outline, visualizing ideas in the form of pictures or charts, and setting goals and sub-goals in writing.

Table 5. Regulation of Cognition (Planning)

\begin{tabular}{llc}
\hline & Item & $\%$ \\
\hline 22 & $\begin{array}{l}\text { Before developing ideas, I always prepare a writing outline or outline of the } \\
\text { writing. }\end{array}$ & 70,79 \\
\hline 23 & $\begin{array}{l}\text { I often make mistakes at the beginning of writing because I often have } \\
\text { difficulty when starting writing. }\end{array}$ & 73,02 \\
\hline 24 & $\begin{array}{l}\text { Before writing, I usually visualize the things that I would write in the form } \\
\text { of pictures, charts or writing frames. }\end{array}$ & 61,27 \\
\hline 25 & $\begin{array}{l}\text { My initial planning in writing was often limited to the language resources } \\
\text { (vocabulary, grammar, and sentence structuring) that I used in writing. }\end{array}$ & 78,10 \\
\hline 26 & I set goals and sub-goals in writing. & 63,81 \\
\hline 27 & I always get used to reading in before writing. & 74,60 \\
\hline
\end{tabular}

The monitoring component in the regulation of cognition is related to the efforts made during writing, including the allocation of time, attention, avoidance, and acceptance of assistance in completing writing assignments. Students have pretty good monitoring awareness. To complete writing assignments, students tend to choose a comfortable environment so they can concentrate, choose the right place and time to write, and try to use time effectively during writing. To make their writing more effective and communicative, they tend to use simple sentences, write according to what they think, according to background knowledge and topics, and always discuss with peers and give each other responses. Some students stated that they were more focused on delivering messages than the details of each piece of writing, trying to focus on the structure and rules of text language, and avoiding vocabulary and grammar that were not understood during writing.

Table 6. Regulation of Cognition (Monitoring)

\begin{tabular}{llc}
\hline & Item & $\%$ \\
\hline 28 & I often write a series of sentences according to what I think. & 78,73 \\
\hline 29 & $\begin{array}{l}\text { At each stage of writing, I use the background knowledge I have in } \\
\text { accordance with the topic to develop my ideas. }\end{array}$ & 70,79 \\
\hline 30 & $\begin{array}{l}\text { I usually focus more on delivering messages than detailed explanations of } \\
\text { each piece of writing. }\end{array}$ & 68,25 \\
\hline 31 & $\begin{array}{l}\text { During writing, I was very focused on the structure of the text and the } \\
\text { linguistic rules of the text and how the two work together to build a text. }\end{array}$ & 65,54 \\
\hline 32 & I can usually use time effectively during writing. & 63,81 \\
\hline 33 & I usually choose the right place and time to write. & 76,83 \\
\hline 34 & I tend to avoid vocabulary and grammar that I don't know during writing. & 76,83 \\
\hline 35 & $\begin{array}{l}\text { When I cannot write with complex sentences, I choose to use simple } \\
\text { sentences as long as my writing is effective and communicative. }\end{array}$ & 79,68 \\
\hline
\end{tabular}


39 I usually have discussions with peers and we respond to each other about 74,60 the topics we write.

40 For me, a comfortable environment greatly affects the writing that I write 87,62 and I always choose that comfortable environment so I can concentrate.

In terms of the evaluation component, students always edit text by paying attention to the structure and rules of text language. Some students even made revisions to the structure of the text and the language rules of the text.

Table 7. Regulation of Cognition (Evaluation)

\begin{tabular}{llc}
\hline & Item & $\%$ \\
\hline 36 & $\begin{array}{l}\text { After I finished writing, I often edited my writing in terms of the structure } \\
\text { and language rules of the text. }\end{array}$ & 73,02 \\
\hline 37 & I often make revisions to the text's language rules. & 66,03 \\
\hline 38 & $\begin{array}{l}\text { I also often make revisions in terms of the completeness of ideas in each part } \\
\text { of the structure of the text. }\end{array}$ & 63,49 \\
\hline
\end{tabular}

The effect of metacognitive awareness on the ability to write explanatory text

Metacognitive awareness is assumed to be a factor affecting the ability to write explanatory texts. In this case, metacognitive awareness as an independent variable $(\mathrm{X})$ that affects the dependent variable $(\mathrm{Y})$, namely: writing explanatory text. To find out how much metacognitive awareness affects the ability to write explanatory text, the Pearson Product Moment correlation formula is used. The results of the Product Moment correlation test are visualized in Table 9 below.

Table 9. Product Moment Correlation Test

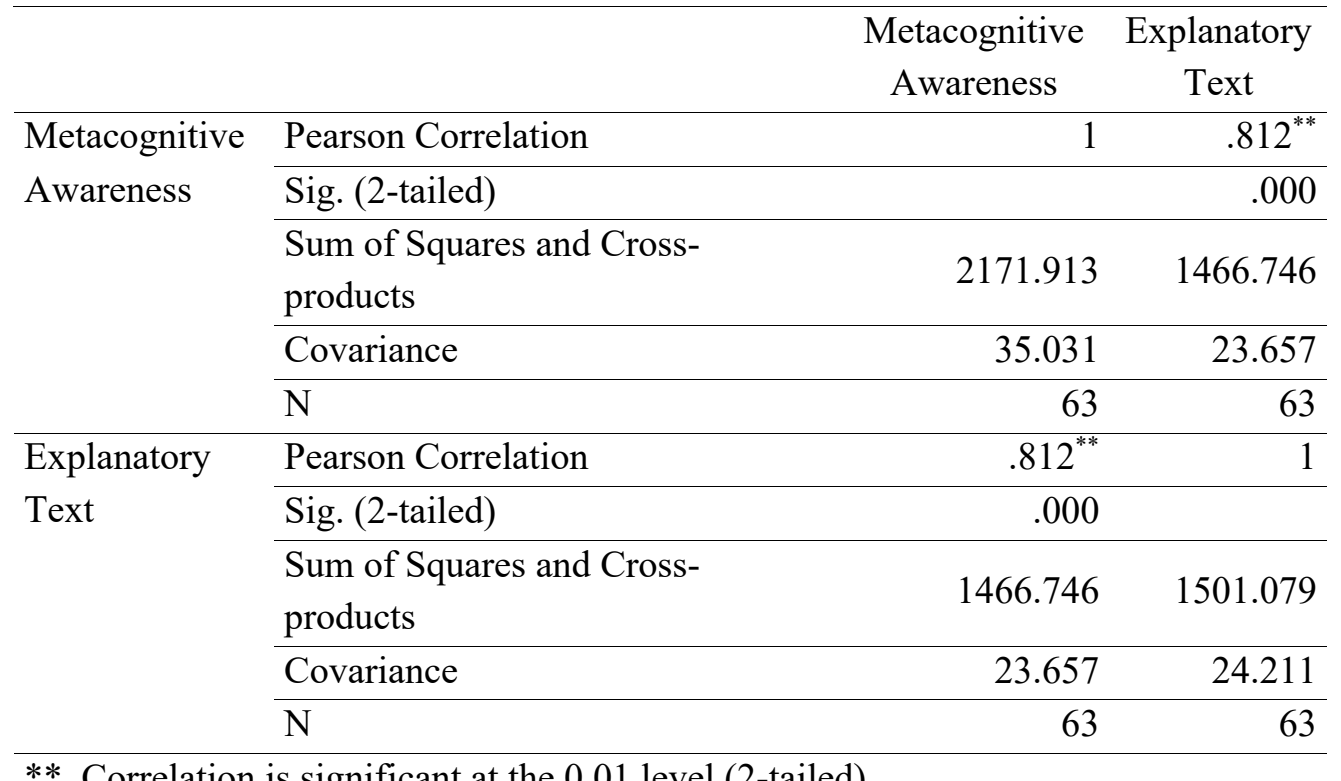

**. Correlation is significant at the 0.01 level (2-tailed).

Based on Table 9 above, the correlation coefficient value of metacognitive awareness and writing explanatory text is $0.812(\mathrm{p}=0.01)$. These results indicate that the relationship between the metacognitive awareness variable and the explanatory text writing variable is 0.812 . This relationship shows a very strong and positive relationship between the two variables because it is in the range $0.80-1.00$. These results also state that the sample who scored high in writing 
explanatory text showed a high score of metacognitive awareness. On the other hand, the sample that scored low in writing explanatory text showed a low score of metacognitive awareness. Thus, the level of a person's metacognitive awareness affects the ability to write explanatory texts.

To find out how much the contribution of metacognitive awareness to the ability to write explanatory text, a significance test of the research variables was carried out as visualized in Table 10 below.

Table 10. Variable Significance Test

\begin{tabular}{lrrrr}
\hline Model & \multicolumn{1}{l}{ R } & R Square & $\begin{array}{c}\text { Adjusted R } \\
\text { Square }\end{array}$ & $\begin{array}{l}\text { Std. Error of } \\
\text { the Estimate }\end{array}$ \\
\hline 1 & $.812^{\mathrm{a}}$ & .660 & .654 & 2.89304 \\
\hline
\end{tabular}

a. Predictors: (Constant), Metacognitive Awareness

Based on Table 10 above, the $t$-test value is 2.89 and the $t$-table for sample 63-2 is 1.67. These results indicate that the $t$-test is greater than the t-table. It can be concluded that there is a significant relationship between metacognitive awareness and the ability to write explanatory texts. Explanatory text writing skills are influenced by metacognitive awareness. Metacognitive awareness is also a determinant of students' writing skills. The higher the level of students' metacognitive awareness, the higher their writing skills. Conversely, the lower the level of students' metacognitive awareness, the lower their writing skills.

The magnitude of the contribution of the metacognitive awareness variable to the ability to write explanatory text seen based on the R-Square value in Table 10 is 0.660 . By using the formula $\mathrm{KP}=\mathrm{r} 2 \times 100 \%$, the value of the contribution of variable $\mathrm{X}$ to variable $\mathrm{Y}$ is $66 \%$. This means: metacognitive awareness is a predictor that affects the ability to write explanatory text by $66 \%$ and the remaining $44 \%$ is influenced by other variables. These results suggest that metacognitive awareness must always be enhanced. A person will be more skilled in writing if he is always aware of his metacognitive skills in completing writing tasks. Implementing metacognitive strategies can increase metacognitive awareness in writing. The quality of writing is highly dependent on the level of one's awareness of metacognition. The higher a person's level of metacognitive awareness, the better the quality of his writing.

\section{Discussion}

The investigation carried out showed that students' metacognitive awareness was at an intermediate level. The average student is unaware of cognition knowledge, especially task knowledge. Students are also not aware of procedural and conditional knowledge so that it affects the quality of explanatory text writing. The investigation specifically shows a number of things, namely: students need intensive training in order to be able to write according to the correct structure and rules of language, students need training by following a series of appropriate writing processes in order to be able to present a coherent paragraph with the development of the right sentence; students need an understanding of various genres of text in order to be able to distinguish each genre of the text, students must understand the tasks and strategies that will be used in writing, often practice using strategies and changing strategies that are not appropriate. Students also experience problems in starting writing because of limited language resources so they tend to use simple sentences, and avoid grammar that is not understood. As a result of students not understanding the genre of the text, students often revise the text in the text structure and language rules because of the limitations of linguistic resources. The investigation proves that limited task 
knowledge will result in weak procedures and ways to be done in writing. All of them have links with each other so that if one is weak, it will affect the others. Knowledge about the task has a relationship with conditional knowledge because it involves an understanding of how to adapt the writing strategy to the requirements of the task (Negretti, 2012) and the strategies used can affect the performance and results of the writing (Hartina, Vianty, \& Inderawati, 2018).

This investigation shows that students are not well aware of their metacognition in writing. Metacognition is seen as a way to regulate and monitor cognition. As applied metacognition, writing is seen as an act of producing meaning, the writer needs to read, reread, and review as a monitoring strategy to ensure that the production of meaning matches the purpose of writing. Word production, word revision, planning, and text production function as responsible controls on the production of actual meanings. The ideas generated as a consequence of the control strategy are monitored and compared with the goals set by the author at the executive level. Some ideas are written and end in the text but others are not. The author must continue to monitor the ideas chosen and those produced, but the ideas produced end up in the text so that the intended purpose of the writer is achieved (Hacker et al., 2009). Students are not well aware of the task and the limitations of linguistic resources in writing so that it can be distinguished the quality of writing produced by students who have high and intermediate metacognitive awareness. The writing is a differentiator of the level of metacognitive awareness of students in writing. In terms of the level of metacognitive awareness, Sitko (2009) distinguishes between adept writers and novice writers in using their cognitive in writing. Advanced writers have knowledge of planning, compilation, revision, and editing. They are also adept at using text structures as tools to produce, organize, and revise texts. They are aware of how written texts function in certain social contexts. They also have a sensitivity to the needs of readers. In contrast to advanced writers, novice writers are not trained in controlling the complex interactions of the skills needed to achieve writing success. They need teaching in the planning process; arrangement; revision; and editing, how to use appropriate text conventions, and how to consider the needs of readers. In the teaching process, novice writers need metacognitive strategies to monitor and control learning so that they will be able to evaluate and integrate strategies into their own repertoires. Ultimately, they will be able to control the complex cognitive and social processes in producing texts and have knowledge of their own cognitions in various contextual and rhetorical purposes.

This once again confirms that students are not skilled in writing because they are less aware of metacognitive knowledge. In fact, metacognitive knowledge has an influence on language proficiency (Guo, 2018). To develop students' metacognitive knowledge, teachers can get students involved in process-based learning, focus on language teaching content, ways and learning processes (Lam, 2009). The teacher needs to design activities that can develop students' knowledge about effective writing strategies (Kasper, 1997). Through process-based writing learning, teachers can guide students in writing. Teachers can use process-based evaluation tools in writing ranging from planning writing, developing ideas and evaluating writing using assessment rubrics. By using process-based evaluation tools in writing, with or without the teacher beside them, they can work on the steps of writing according to the process listed in the evaluation tool (Ramadhanti, Yanda, et al., 2019).

The process approach in writing will help students grow their metacognitive awareness when implemented through a metacognitive strategy. Metacognitive strategies in writing will be formed with training and practice. Metacognitive strategies can be formed by developing metacognitive knowledge and increasing metacognitive awareness. Generating awareness in writing can be done by: asking questions about the cognitive level of individual writers with the 
level of writing, comparison of one's own writing with other people's writings, and factors that influence the level of writing and writing activities, helping students understand the task of writing by telling them the nature of writing, knowledge, and basic writing methods, helping students analyze the purpose of writing and the requirements of concrete writing assignments, and explain the use of strategies to them, and enrich students' experience by asking them to ask themselves to monitor and evaluate the processes that have been carried out in write (Fenghua Lv \& Chen, 2010). In addition, the metacognitive strategy is a term used in information processing theory to indicate executive function and refers to strategies used by someone as a means to manage, monitor and evaluate their learning activities. In short, metacognition strategies are the skills, approaches, and thoughts and actions that students use to control their cognition and learning processes (Oxford, 1990:136). Metacognitive strategies aim at metacognitive goals, for assessing knowledge, and can produce metacognitive experiences. Metacognitive experiences can influence the metacognitive knowledge base by adding, removing, or revising them (Flavell, 1979).

Metacognitive strategies in influencing and improving the quality of the contents of writing because this strategy requires high-level thinking skills (Pitenoee, Modaberi, \& Ardestani, 2017). Students need to be trained to use metacognitive strategies in writing ranging from planning writing, developing ideas, and evaluating writing (Goctu, 2017). Metacognitive strategies in writing can be combined with cognitive learning models (Fenghua Lv \& Chen, 2010) and can also use mind-mapping strategies (Putra, 2012; Ramadhanti \& Mana, 2018) to map ideas at the planning stage of writing, and Genre-Based Instruction to improve students' competence and confidence in writing (Thongchalerm \& Jarunthawatchai, 2020). The teacher must also always encourage students to reflect on their learning. As students reflect on their learning strategies, they become better equipped to make conscious decisions about what they can do to improve their learning (N. J. Anderson, 2002). It is important to realize that metacognition is central in the process of independent learning (Handel, Artelt, \& Weinert, 2013) and become an integral part of learning to write (Xiao, 2007). Metacognition is also an important aspect of human intelligence (Schraw, Crippen, \& Hartley, 2006), but does not depend on intelligence (Veenman, Wilhelm, \& Beishuizen, 2004). Metacognition helps students to find their weaknesses which can then be corrected by implementing new strategies (Tosuncuoğlu \& Kırmızı, 2019).

By teachers using metacognitive strategies in the learning process, indirectly the teacher has instilled metacognitive skills to students in the learning process. Metacognitive skills can help students organize their learning, promote independent learning, and improve task performance (Maduabuchi, Ogbonnaya, \& Angela, 2016). So that students have metacognitive skills needed a special method. (Lestari, Ristanto, \& Miarsyah, 2019), for example, the teacher provides authentic material for teaching writing (Setyowati \& Sukmawan, 2019) and uses contemplative teaching practices to facilitate the student's writing process (Chaterdon \& College, 2019), complemented by performance-based assessments (Suastra \& Menggo, 2020) or provide remedial and corrective feedback (Maawa \& Cruz, 2019) on students' writing. Through this contemplative practice, students are taught to use internal reflection (cognition) and external reflection (genre and audience). During this activity, students do self-questioning. All of that was recorded using a learning journal (McCrindle \& Christensen, 1995); (Clipa, Ignat, \& Stanciu, 2012) or reflective journal (Henter \& Indreica, 2016). By reading reflective journals written by students, teachers can find out students' beliefs about assignments and how to do assignments, so that teachers can help students to develop more effective learning strategies in the classroom (Horwitz, 1988). In addition to developing metacognitive awareness, journals writing can also help foster student metacognition in writing, namely awareness of knowledge and task completion efforts, monitoring 
the process and quality of results obtained, and habits to plan, set goals, and implement certain strategies in completing assignments (Ramadhanti, Ghazali, Hasanah, Harsiati, \& Yanda, 2020).

\section{Conclusion}

Investigations on students' metacognitive in writing showed that metacognitive awareness was the main factor affecting explanatory text writing skills. Students who have high metacognitive awareness have good abilities in writing explanatory text, while students who have low metacognitive awareness have low abilities in writing explanatory text. Metacognitive awareness needs to be increased by students, especially metacognition knowledge. Students need intensive training in order to be able to write according to the structure and rules of the language of the text. Students need to be trained through an intensive writing process to be able to present coherent texts and develop appropriate sentences in paragraphs. Students also need to be trained to write in a variety of text genres so that they can recognize the differences in each genre of text and consider the audience in writing activities. Students often have difficulty writing because of limited linguistic resources so they tend to use simple sentences and avoid grammar that is poorly understood. When evaluating written texts, students must always revise the accuracy of the text structure and linguistic rules. Students must better understand the tasks and strategies used in writing. Students must often practice using certain strategies in writing, knowing clearly when to use strategies, and when to replace less effective strategies with more effective strategies. This implies that the teacher must make a series of efforts so that students can increase their metacognitive awareness.

Knowledge of metacognitive can be improved by the teacher using a cognitive processbased approach in writing activities. Students will be trained to write starting from planning ideas, developing ideas, and evaluating writing. To develop ideas, teachers can direct students to create writing frameworks in the form of mind mapping, charts, and so on. To develop ideas, students can be directed to read and recall previous knowledge and experience to be linked into a text. To evaluate writing, the teacher can apply the collaborative method so that the discussion process occurs and respond to each other on the results of the writing. The teacher acts as a facilitator not a corrector of linguistic elements. All writing processes can be carried out through a metacognitive strategy. Students who are often trained to write using metacognitive strategies will have metacognitive skills. He will get used to using certain strategies in writing so that he will know and realize which strategies are effective and which are not effective in writing. All of this can be done if the teacher continues to provide encouragement to students and provide appropriate feedback to improve student writing skills. This study does not explain the application of metacognitive strategies as an effort to train students' metacognitive skills. Further research can be directed at the application of metacognitive strategies equipped with metacognitive development monitoring tools, such as self-reports, reflective journals, error analysis assessments, and thinkaloud protocols.

Declaration of conflicting interest

The authors hereby declare that there is no conflict interest concerning the publication of this manuscript into the International Journal of Language Education (IJOLE).

Funding acknowledgement

The authors received no specific funding for this work. 


\section{References}

Anderson, M., \& Anderson, K. (1997). Text Types in English 1. South Yarra: MacMillan Education Australia.

Anderson, N. J. (2002). The Role of Metacognition in Second Language Teaching and Learning. ERIC Digest, 1(10), 2-5.

Chaterdon, K., \& College, M. (2019). Writing into Awareness: How Metacognitive Awareness Can Be Encouraged through Contemplative Teaching Practices. Across the Disciplines, $16(1), 50-65$.

Clipa, O., Ignat, A. A., \& Stanciu, M. (2012). Learning Diary as a Tool for Metacognitive Strategies Development. Procedia - Social and Behavioral Sciences, 33, 905-909. https://doi.org/10.1016/j.sbspro.2012.01.253

Farahian, M. (2015). Assessing EFL Learners' Writing Metacognitive Awareness. Journal of Language and Linguistic Studies, 11(2), 39-51.

Farahian, M. (2017). Developing and validating a metacognitive writing questionnaire for EFL learners. Issues in Educational Research, 27(4), 736-750.

Fenghua Lv, \& Chen, H. (2010). A Study of Metacognitive-Strategies-based Writing Instruction for Vocational College Students. English Language Teaching, 3(3), 136-144. Retrieved from www.ccsenet.org/elt

Fitri, R., \& Ramadhanti, D. (2019). Buku Ajar Statistika Pendidikan. Padang: STKIP PGRI Sumbar Press.

Flavell, J. H. (1979). Metacognition and Cognitive Monitoring A New Area of Cognitive Developmental Inquiry. American Psychologist, 34(10), 906-911. https://doi.org/10.1037/0003-066x.34.10.906

Flower, L., \& Hayes, J. R. (1981). A Cognitive Process Theory of Writing. College Composition and Communication, 32(4), 365. https://doi.org/10.2307/356600

Goctu, R. (2017). Metacognitive Strategies in Academic Writing. Journal of Education in Black Sea Region, 2(2), 82-96.

Greenberg, K. L. (1988). Assessing Writing: Theory and Practice. New Direction for Teaching and Learning, 34, 47-59. https://doi.org/10.1002/tl.37219883406

Guo, L. (2018). Modeling the Relationship of Metacognitive Knowledge, L1 Reading Ability, L2 Language Proficiency and L2 Reading. Reading in a Foreign Language, 30(2), 209-231.

Hacker, D. J., Keener, M. C., \& Kircher, J. C. (2009). Writing is Applied Metacognition. In D. J. Hacker, J. Dunlosky, \& A. C. Graesser (Eds.), Handout of Metacognition in Education (pp. 154-172). New Jersey: Routledge.

Handel, M., Artelt, C., \& Weinert, S. (2013). Assessing Metacognitive Knowledge: Development and Evaluation of a Test Instrument. Journal for Educational Research, 5(2), 162-188.

Harris, K. R., Graham, S., Brindle, M., \& Sandmel, K. (2009). Metacognitive and Children's Writing. In D. J. Hacker, J. Dunslosky, \& A. C. Graesser (Eds.), Handbook of Metacognition in Education (pp. 131-153). New York: Routledge.

Hartina, S. S., Vianty, M., \& Inderawati, R. (2018). Correlation Between Students 'Metacognitive Strategy Used in Writing Process and Essay Writing Performance. The Journal of English Literacy Education, 5(2), 158-167.

Henter, R., \& Indreica, E. S. (2016). Reflective Journal Writing as a Metacognitive Tool. In International Conference of Scientific Paper.

Horwitz, E. K. (1988). The Beliefs About Language Learning of Beginning University Foreign Language Students. The Modern Language Journal, 72(3), 283-294. 
Iwai, Y. (2011). The Effects of Metacognitive Reading Strategies: Pedagogical Implications for EFL/ESL Teachers. The Reading Matrix, 11(2), 150-159.

Kasper, L. F. (1997). Assessing the Metacognitive Growth of ESL Student Writters. Teaching English as a Second or Foreign Language Journal (TESF-LJ), 3(1).

Lam, W. Y. K. (2009). Examining the Effects of Metacognitive Strategy Instruction on ESL Group Discussions: A Synthesis of Approaches. Language Teaching Research, 13(2), 129-150. https://doi.org/10.1177/1362168809103445

Lestari, P., Ristanto, R. H., \& Miarsyah, M. (2019). Analysis of Conceptual Understanding of Botany and Metacognitive Skill in Pre-Service Biology Teacher in Jakarta Indonesia. Journal for the Education of Gifted Young Scientists, 7(2), 199-214. https://doi.org/10.17478/jegys.515978

Maawa, P. K. L., \& Cruz, R. O. Dela. (2019). Remedial and Corrective Feedback Strategies for Improving Students' English Language Proficiency. International Journal of Language Education, 3(1), 1-11. https://doi.org/10.26858/ijole.v1i1.7794

Maduabuchi, C. H., Ogbonnaya, I., \& Angela, I. (2016). Teaching Metacognitive Skills for the Promotion of Self-Regulated Learning Among Secondary School Students in Nigeria. British Journal of Education, 4(10), 74-84.

Maftoon, P., Birjandi, P., \& Farahian, M. (2014). Investigating Iranian EFL learners' Writing Metacognitive Awareness. International Journal of Research Studies in Education, 3(5), $37-$ 51. https://doi.org/10.5861/ijrse.2014.896

Marzano, R. J., Brandt, R. S., Hughes, C. S., Jones, B. F., Presseisen, B. Z., Rankin, S. C., \& Suhor, C. (1987). Dimension of Thinking: Framework for Curriculum and Instruction. Alexandria: Association for Supervisor and Curriculum Development.

McCrindle, A. R., \& Christensen, C. a. (1995). The Impact of Learning Journals on Metacognitive and Cognitive Processes and Learning Performance. Learning and Instruction, 5(2), 167185. https://doi.org/10.1016/0959-4752(95)00010-Z

Negretti, R. (2012). Metacognition in Student Academic Writing: A Longitudinal Study of Metacognitive Awareness and Its Relation to Task Perception and Evaluation of $\begin{array}{llll}\text { Performance. } \quad \text { Communication, } & \text { 29(2), }\end{array}$ https://doi.org/http://dx.doi.org/10.1177/0741088312438529

Owens, R. E. (2012). Language Development: An Introduction (8th ed.). New Jersey: Pearson Education, Inc.,Upper Saddle River. https://doi.org/013258252X

Oxford, R. L. (1990). Language Learning Strategies: What Every Teacher Should Know. Boston: Heinle.

Pitenoee, M. R., Modaberi, A., \& Ardestani, E. M. (2017). The Effect of Cognitive and Metacognitive Writing Strategies on Content of the Iranian Intermediate EFL Learners' Writing. Journal of Language Teaching and Research, 8(3), 594-600. https://doi.org/http://dx.doi.org/10.17507/jltr.0803.19

Putra, P. P. (2012). The Use of Mind Mapping Strategy in the Teaching of Writing at SMAN 3 Bengkulu, Indonesia Riswanto State Institute of Islamic Studies (IAIN) Bengkulu, Indonesia. International Journal of Humanities and Social Science, 2(21), 60-68. Retrieved from www.ijhssnet.com

Ramadhanti, D., Ghazali, A. S., Hasanah, M., \& Harsiati, T. (2019). Students' Metacognitive Weaknesses in Academic Writing: A Preliminary Research. International Journal of Emerging Technologies in Learning (IJET), 14(11), 41-57. https://doi.org/10.3991/ijet.v14i11.10213 
Ramadhanti, D., Ghazali, A. S., Hasanah, M., Harsiati, T., \& Yanda, D. P. (2020). The Use of Reflective Journal as a Tool for Monitoring of Metacognition Growth in Writing. International Journal of Emerging Technologies in Learning (IJET), 15(11), 162-187. https://doi.org/10.3991/ijet.v15i11.11939

Ramadhanti, D., \& Mana, L. A. (2018). Comparison of Brainstorming and Mind Mapping Techniques in Argumentation Writing Learning. Curricula: Journal of Teaching and Learning, 3(3), 159-171. https://doi.org/10.22216/jcc.2018.v3i3.2024

Ramadhanti, D., Yanda, D. P., Ghazali, A. S., Hasanah, M., \& Harsiati, T. (2019). Development of Explanatory Text Writing Evaluation Tools Based on a Process Approach (Pengembangan Alat Evaluasi Menulis Teks Eksplanasi Berbasis Pendekatan Proses). Jurnal Gramatika: Jurnal Penelitian Pendidikan Bahasa Dan Sastra Indonesia, 5(2), 194210. https://doi.org/https://doi.org/10.22202/JG.2019.V5i2.3445

Schraw, G., Crippen, K. J., \& Hartley, K. (2006). Promoting Self-Regulation in Science Education: Metacognition as Part of a Broader Perspective on Learning. Research in Science Education, 36, 111-139. https://doi.org/10.1007/s11165-005-3917-8

Setyowati, L., \& Sukmawan, S. (2019). Authentic Materials for Teaching Writing: A Critical Look. International Journal of Language Education, 3(2), 68-77. https://doi.org/10.26858/ijole.v3i2.9609

Sitko, B. M. (2009). Knowing How to Write: Metacognition and Writing Instruction. In D. J. Hacker, J. Dunlosky, \& A. J. Graesser (Eds.), Metacognition in Educational Theory and Practice (1st ed., pp. 93--115). New York: Routledge: Taylor \& Francis Group.

Suastra, I. M., \& Menggo, S. (2020). Empowering Students' Writing Skill through Performance Assessment. International Journal of Language Education, 4(3), 432-441. https://doi.org/10.26858/ijole.v4i3.15060

Surat, S., Rahman, S., Mahamod, Z., \& Kummin, S. (2014). The Use of Metacognitive Knowledge in Essay Writing Among High School Students. International Education Studies, 7(13), 212-218. https://doi.org/10.5539/ies.v7n13p212

Thongchalerm, S., \& Jarunthawatchai, W. (2020). The Impact of Genre Based Instruction on EFL Learners' Writing Development. International Journal of Instruction, 13(1), 1-16. https://doi.org/10.29333/iji.2020.1311a

Tosuncuoğlu, İ., \& Kırmızı, Ö. (2019). A Review on Writing Metacognitive Awareness of Turkish Advanced Level EFL Learners. International Online Journal of Education and Teaching (IOJET), $6(1)$ 136-149. https://doi.org/http://www.iojet.org/index.php/IOJET/article/view/562

Veenman, M., Wilhelm, P., \& Beishuizen, J. J. (2004). The Relation Between Intellectual and Metacognitive Skills from a Developmental Perspective. Learning and Instruction, 14, 89109. https://doi.org/10.1016/j.learninstruc.2003.10.004

Xiao, Y. (2007). Applying Metacognition in EFL Writing Instruction in China. Reflections on English Language Teaching, 6(1), 19-33. Retrieved from http://www.nus.edu.sg/celc/publications/RELT61/p19to34xiao.pdf. 